dr inż. Anita RICHERT-KAŹMIERSKA

Wydział Zarządzania i Ekonomii, Politechnika Gdańska

e-mail: Anita.Richert@zie.pg.gda.pl

DOI: $10.15290 /$ oes.2018.01.91.02

\title{
DYSKRYMINACJA VERSUS ADMIRACJA. PRACOWNICY W STARSZYM WIEKU W WYBRANYCH TEORIACH I KONCEPCJACH EKONOMICZNYCH
}

\begin{abstract}
Streszczenie
Wśród konsekwencji postępującego starzenia się ludności literatura przedmiotu wymienia m.in. ilościowe i jakościowe zmiany na rynku pracy. Zwraca uwagę na malejace potencjalne i realne zasoby pracy oraz ich starzenie się, tj. rosnący wśród pracujących udział osób „w starszym wieku”. Celem opracowania jest próba zdefiniowania pojęcia pracownika „w starszym wieku” oraz diagnoza i klasyfikacja podejść do tej grupy, zawartych w wybranych teoriach i koncepcjach ekonomicznych.
\end{abstract}

Słowa kluczowe: starzenie się ludności, rynek pracy, pracownik w starszym wieku, dyskryminacja ze względu na wiek

\section{DISCRIMINATION VERSUS ADMIRATION. OLDER WORKERS IN SELECTED ECONOMIC THEORIES AND CONCEPTS}

\section{Summary}

Among the other consequences of population aging the scientific literature lists quantitative and qualitative changes in the availability of the labor force. Authors draw their attention to the declining potential of labor resources and their aging, mainly because of the increasing share of older persons among workers. The main aim of the study was to define the concept of "older worker" and to diagnose and classify approaches to this group in selected economic theories and concepts.

Key words: population aging, labour market, older worker, age discrimination

JEL classification: J01, J11, J14 


\section{Wstęp}

Starzenie się ludności to zjawisko globalne [Kijak, Szarota, 2013, s. 6]. Oznacza ono zmiany w strukturze wieku ludności, polegające na rosnącej liczbie i udziale osób reprezentujących starsze grupy wiekowe w populacji ogółem. Pociaga za sobą zmiany jakościowe - na różnych poziomach życia społecznego i gospodarczego [Szatur-Jaworska, 2013, s. 348].

Rynek pracy stanowi jeden $\mathrm{z}$ wymiarów, w którym konsekwencje starzenia się ludności dostrzec można najwyraźniej. Obejmują one m.in.: systematycznie malejące potencjalne i realne zasoby pracy, zmieniającą się strukturę wieku osób aktywnych zawodowo (średnia i mediana wieku rosna), rosnace zapotrzebowanie na pracowników świadczących usługi z zakresu opieki zdrowotnej i pomocy społecznej, rozwój w przedsiębiorstwach nowych systemów zarządzania zasobami ludzkimi, w tym zarządzania wiekiem.

Podstawowym sposobem przeciwdziałania procesowi zmniejszania się zasobów pracy jest aktywizacja i włączanie w rynek pracy osób tradycyjnie pozostających biernymi zawodowo. Literatura przedmiotu [Rynek pracy i aykluczenie społeczne, 2014] wskazuje w tym miejscu m.in.: kobiety, osoby niepełnosprawne, osoby reprezentujące mniejszości narodowe i etniczne oraz osoby w starszym wieku - przedwcześnie decydujące się na skorzystanie $z$ emerytury. Potencjał ostatniej grupy wydaje się nie do przecenienia. Jej członkowie posiadają doświadczenie zawodowe i życiowe oraz wiedzę i umiejętności, często specjalistyczne i unikatowe. Mimo to, w miejscu pracy doświadczają dyskryminacji ze względu na swój wiek, co przyspiesza ich decyzje o ostatecznym wycofaniu się z rynku pracy i przejściu na emeryturę [Górniak, 2013].

Celem opracowania jest próba zdefiniowania pojęcia pracownika „w starszym wieku" oraz diagnoza i klasyfikacja podejść do tej grupy zawartych w wybranych teoriach i koncepcjach ekonomicznych.

\section{Pracownik w starszym wieku - czyli w jakim wieku?}

Demograficzne starzenie się ludności w perspektywie rynku pracy oznacza kurczące się potencjalne i realne zasoby pracy oraz zmianę struktury wieku osób pracujących, ze wskazaniem na rosnący udział wśród pracowników osób reprezentujących starsze grupy wiekowe [Richert-Kaźmierska, 2017]. W literaturze przedmiotu są oni określani jako: „starsi pracownicy” lub „pracownicy w starszym wieku”.

Autorzy najczęściej utożsamiaja „starszych pracowników” z osobami w wieku 50 lat i więcej ${ }^{1}$. Tymczasem, tak zdefiniowana grupa jest silnie wewnętrznie zróżnicowana: ze względu na zaawansowanie zmian wywołanych starzeniem się

1 Granicę wieku 50 lat i więcej przyjmuje się jako klasyfikującą do grupy „starszych pracowników” m.in. ze względu na zapisy ustawy o promocji zatrudnienia i instytucjach rynku pracy [2004], które osobom powyżej 50. roku życia przyznają status „będących w szczególnej sytuacji”. 
organizmu [Nowicka 2008, s. 17; Przetacznik-Gierowska, Tyszkowa, 2004, s. 31] oraz zdefiniowany wiekiem chronologicznym status na rynku pracy².

Aby uwydatnić najbardziej znaczące różnice wewnętrzne subpopulacji osób w wieku 50 lat i więcej, można podzielić ją na dwie grupy: „,starzy-starzy” i „,młodzistarzy" (por. tabela 1). W opracowaniach anglojezzycznych osoby klasyfikowane do grupy starsy-starzy nazywani są także old-old, seniors, veterans generation lub traditionalists [Huber, Skidmore, 2003; Tolbize, 2008; Browning, Worman, 2008; Richert-Kaźmierska, 2013; Generational differences, 2016]. Sa to osoby urodzone w latach 1900-1945, które de facto zakończyły już okres aktywności zawodowej. „Młodzi-starzy” to z kolei osoby urodzone w latach 1946-1964, w okresie powojennego wyżu demograficznego (stąd w literaturze anglojęzycznej nazwa baby boomers), znajdujące się w szczytowej fazie swoich osiagnięć zawodowych [Baby boomers envision their retirement, 1999; Macunovich, 2000]. Przedstawiciele tej grupy dominują aktualnie w świecie biznesu i polityki, podejmuja kluczowe decyzje polityczno-gospodarcze i społeczne w skali globalnej [Pirie, Worcester, 1998]. Sa aktywni zawodowo, społecznie i towarzysko, są mobilni, chętnie wykorzystuja nowoczesne technologie [Jacobs, Worcester, 1990; Generational differences, 2016].

TABELA 1.

Niejednorodność populacji w wieku 50 lat i więcej - grupa „starzy-starzy” i „,młodzi-starzy”

\begin{tabular}{|c|c|c|}
\hline $\begin{array}{c}\text { Wybrane } \\
\text { charakterystyki }\end{array}$ & „Starzy-starzy” & „Młodzi-starzy” \\
\hline Rok urodzenia & $1900-1945$ & 1946-1964 \\
\hline Wiek & 72 lata $i$ więcej & 53-71 lat \\
\hline $\begin{array}{l}\text { Określenia stoso- } \\
\text { wane w literaturze } \\
\text { anglojęzycznej }\end{array}$ & $\begin{array}{l}\text { seniors, veterans, traditionalists, } \\
\text { silent generation, the forgotten } \\
\text { generation }\end{array}$ & baby boomers, „me” generation \\
\hline $\begin{array}{l}\text { Podstawowe } \\
\text { wartości }\end{array}$ & $\begin{array}{l}\text { przestrzeganie zasad, } \\
\text { konformizm, dobro wspólne } \\
\text { ważniejsze niż partykularne } \\
\text { interesy, obowiązek ponad } \\
\text { przyjemnością, wartości } \\
\text { rodzinne, patriotyzm, prawo } \\
\text { i porządek, cierpliwość, } \\
\text { szacunek dla autorytetów, } \\
\text { oszczędność, odpowie- } \\
\text { dzialność }\end{array}$ & $\begin{array}{l}\text { sprzeciw wobec wojny, gotowość } \\
\text { występowania przeciwko władzy } \\
\text { i autorytetom, bezkompromiso- } \\
\text { wość, równouprawnienie, wiara } \\
\text { we własne możliwości i sukces, } \\
\text { optymizm, osobista satysfakcja, } \\
\text { współpraca z poszanowaniem } \\
\text { indywidualizmu, praca, chęć } \\
\text { zmian }\end{array}$ \\
\hline
\end{tabular}

2 Według nomenklatury pojęciowej Głównego Urzędu Statystycznego osoby w wieku produkcyjnym to mężczyźni w wieku 18-64 lata oraz kobiety w wieku 18-59 lat. Osoby w wieku produkcyjnym: mężczyźni 45-64 lata, kobiety 45-59 lat - klasyfikowane sa jako niemobilne (tj. o niższej zdolności adaptacyjnej do warunków rynku pracy i niższej aktywności ekonomicznej). Wiek poprodukcyjny wyznaczaja granice: dla mężczyzn - 65. rok życia, dla kobiet - 60. rok życia. 


\begin{tabular}{|l|l|l|}
\hline \multicolumn{1}{|c|}{$\begin{array}{c}\text { Wybrane } \\
\text { charakterystyki }\end{array}$} & \multicolumn{1}{|c|}{ „Starzy-starzy” } & \multicolumn{1}{c|}{ „Młodzi-starzy” } \\
\hline Cechy & $\begin{array}{l}\text { profesjonalizm, gotowość } \\
\text { do poświęceń, gotowość } \\
\text { do ciężkiej pracy, } \\
\text { patriotyzm, zaufanie, } \\
\text { podporządkowanie } \\
\text { zasadom, konserwatyzm, } \\
\text { uległość }\end{array}$ & $\begin{array}{l}\text { zdolności rozwiązywania proble- } \\
\text { mów i wychodzenia z sytuacji } \\
\text { kryzysowych, ambicje, profesjo- } \\
\text { nalizm, gotowość do konkuro- } \\
\text { wania, konsumeryzm, zaangażo- } \\
\text { wanie w pracę, lojalność wobec } \\
\text { pracodawcy, elastyczność }\end{array}$ \\
\hline $\begin{array}{l}\text { Preferencje } \\
\text { dotyczące } \\
\text { organizacji pracy }\end{array}$ & $\begin{array}{l}\text { tradycyjna, hierarchiczna } \\
\text { organizacja, relacje w opar- } \\
\text { ciu o hierarchę służbowa, } \\
\text { zarządzanie, ,z góry na dół” }\end{array}$ & $\begin{array}{l}\text { płaska struktura organizacyjna, } \\
\text { demokratyczny styl zarządzania, } \\
\text { równość szans, przyjazne } \\
\text { środowisko pracy }\end{array}$ \\
\hline $\begin{array}{l}\text { Praca stanowi... } \\
\text { obowiązek }\end{array}$ & $\begin{array}{l}\text { wyzwanie, ekscytująca przygodę, } \\
\text { możliwość rozwoju }\end{array}$ \\
\hline $\begin{array}{l}\text { Stosunek do } \\
\text { emerytury }\end{array}$ & $\begin{array}{l}\text { należny, wyczekiwany wypo- } \\
\text { czynek po ciężkiej pracy, } \\
\text { odcięcie się od jakiejkolwiek } \\
\text { aktywności zawodowej }\end{array}$ & $\begin{array}{l}\text { praca jako wartość podstawowa, } \\
\text { kontynuacja aktywności zawo- } \\
\text { dowej także po przekroczeniu } \\
\text { formalnego wieku emerytalnego, } \\
\text { w tym w zredukowanym czasie }\end{array}$ \\
\hline
\end{tabular}

Źródło: [Generational differences, 2016].

Inne kryteria wykorzystywane w literaturze przedmiotu do klasyfikowania grupy „starszych pracowników” to: wiek produkcyjny niemobilny (45-64 lata mężczyźni i 45-59 lat kobiety), wiek poprodukcyjny (mężczyźni w wieku 65 lat i więcej oraz kobiety - 60 lat $i$ więcej), a także tzw. wiek okołoemerytalny. W ostatnim przypadku jest to dla kobiet wiek od 50. do 65. roku życia i mężczyzn od 55. do 70. roku życia [Dezaktywacja osób w wieku okotoemerytalnym, 2008, s. 9; Richert-Kaźmierska, Wojciechowska, 2012, s. 17].

\section{Wybrane teorie ekonomii o pracownikach w starszym wieku}

W teorii ekonomii wiele miejsca poświęca się zagadnieniom związanym z pracą [Wilsz, 2009; Gerlach, 2008; Spychalski, 1999; Nowak, 2011], funkcjonowaniem rynku pracy [Kryńska, Kwiatkowski, 2013; Zieliński, 2008; Unolt, 1996; Gawrycka, 2011], bezrobociu, w tym jego przyczynom, skutkom i sposobom rozwiązywania problemu [Borkowski, Marcinkowski, 1996; Kwiatkowski 2002; Budnikowski, 2002], a także uwarunkowaniom, strukturze i formom zatrudnienia [Kwiatkowski, 2002; Kwiatkowska, 2007; Gawrycka, 2011].

Ze względu na zachodzące zmiany demograficzne, polegające na zwiększaniu się liczby i udziału osób reprezentujących starsze grupy wiekowe w potencjalnych i realnych zasobach pracy, interesujący wydaje się opis tej grupy (jej specyfiki i znaczenia dla funkcjonowania rynku pracy) w teoriach i koncepcjach ekonomicznych. Proponowaną klasyfikację, stanowiąca wynik analizy literaturowej przeprowadzonej przez autorkę, zawarto w tabeli 2. 
TABELA 2.

\section{Pracownicy w starszym wieku - klasyfikacja podejść w wybranych teoriach i koncepcjach ekonomicznych}

\begin{tabular}{|l|l|}
\hline \multicolumn{1}{|c|}{ Typ } & \multicolumn{1}{|c|}{\begin{tabular}{c}
\multicolumn{1}{c|}{ Teorie i koncepcje ekonomiczne opisujące } \\
wyodrębniony typ
\end{tabular}} \\
\hline Cenny pracownik & $\begin{array}{l}\text { teoria kapitału ludzkiego [Munnell, Sass, 2008; Greller, } \\
\text { Simpson, 1999] }\end{array}$ \\
\hline $\begin{array}{l}\text { Nieefektywny } \\
\text { pracownik }\end{array}$ & $\begin{array}{l}\text { koncepcja produktywności w cyklu życia [Feyrer, 2004; } \\
\text { Silverstein, 2008], koncepcja wage-productivity gap [Lazear, } \\
\text { 1979; Skirbekk, 2004] }\end{array}$ \\
\hline $\begin{array}{l}\text { Gorszy (niż młodszy) } \\
\text { kandydat na pracownika }\end{array}$ & $\begin{array}{l}\text { segmentacja i dyskryminacja statystyczna [Zwiech, 2013; } \\
\text { Kryńska, Kwiatkowski, 2013] }\end{array}$ \\
\hline $\begin{array}{l}\text { Gorszy (niż młodszy) } \\
\text { pracownik }\end{array}$ & $\begin{array}{l}\text { koncepcja rynku dualnego [Piore, 1979; Kryńska, } \\
\text { Kwiatkowski, 2013] }\end{array}$ \\
\hline „Trudny” bezrobotny & $\begin{array}{l}\text { teoria alokacji i poszukiwań pracy [Kryńska, 1998], } \\
\text { koncepcja krzywej Beveridge'a [Ghayad, 2013] }\end{array}$ \\
\hline Młody emeryt & $\begin{array}{l}\text { teoria wycofania [Kunemund, Kolland, 2007], koncepcja } \\
\text { modelu push-pull [Angus, Reeve, 2006] }\end{array}$ \\
\hline $\begin{array}{l}\text { Aktywny (zawodowo) } \\
\text { senior }\end{array}$ & $\begin{array}{l}\text { teoria aktywności [Havighurst, 1961; Cavan, 1962], teoria } \\
\text { ciagłości [Atchley, 1989]; koncepcja gotowości do pracy - } \\
\text { work ability concept [Tuomi et al., 1998] }\end{array}$ \\
\hline
\end{tabular}

Źródło: opracowanie własne.

W założeniach teorii kapitału ludzkiego nie ma bezpośrednich odniesień do wieku pracownika jako determinanty jego użyteczności dla organizacji i aktywności na rynku pracy. Kapitał ludzki definiowany jest jako zasób wiedzy, umiejętności, zdrowia, siły i energii witalnej zawartych w człowieku [Domański, 1993, s. 35]. Perspektywa wieku nosiciela (właściciela) kapitału ludzkiego pojawia się w promowanym przez niektórych autorów [Domański, 1993, s. 20; Kunasz, 2004, s. 440] przekonaniu o możliwości powiększania kapitału ludzkiego w czasie. Służyć temu mają inwestycje jednostki w siebie (m.in. aktywność edukacyjna), które ostatecznie decyduja o jakości kapitału ludzkiego reprezentowanej na kolejnych etapach rozwoju zawodowego oraz przyszłych zyskach [Kunasz, 2004, s. 438]. W modelu wzrostu gospodarczego, uwzględniającym zróżnicowanie ilości i jakości kapitału ludzkiego, Manuelli i Seshadri [2005] dowodza, że bardzo szybki wzrost zasobu kapitału ludzkiego jednostki następuje w okresie szkolnym. W okresie życia zawodowego początkowo zasób kapitału ludzkiego nadal rośnie, ale w miarę jak jednostka coraz mniej inwestuje $\mathrm{w}$ jego produkcję wzrost staje się coraz wolniejszy. W okresie przedemerytalnym, deprecjacja kapitału ludzkiego staje się szybsza od jego produkcji i ostatecznie zasób kapitału ludzkiego zaczyna maleć. Pomimo tego, że na ostatnim etapie życia zawodowego może następować ubytek kapitału ludzkiego, w teorii kapitału ludzkiego docenia się zakumulowaną przez lata pracy wiedzę 


\section{i doświadczenie pracowników reprezentujących starsze grupy wiekowe [Munnell, Sass, 2008].}

To one - wiedza i doświadczenie - wskazywane są przez pracodawców jako cechy wyróżniające starszych pracowników spośród innych (młodszych) pracowników. Wyniki badań Turka i Perek-Białas [2013, s. 653] pokazuja, że pracodawcy cenią starszych pracowników ${ }^{3}$ za ich umiejętności zarządcze, rzetelność i lojalność. W raporcie z badań opinii pracodawców na temat zatrudniania pracowników w wieku 45 lat i więcej, wśród argumentów przemawiających za zatrudnianiem i motywowaniem do pozostawania starszego pracownika $\mathrm{w}$ miejscu pracy, wymieniono „bogate doświadczenie zawodowe, samodzielność, odpowiedzialność, terminowość, oddanie pracy, dyspozycyjność oraz lojalność" [Fryca, Maciejewska, 2010, s. 44]. Pracodawcy z województwa pomorskiego zapytani o to dlaczego zatrudniaja pracowników w wieku 45 lat i więcej, wskazywali przede wszystkim: posiadane przez nich kwalifikacje i kompetencje zawodowe $(54,5 \%)$, posiadane umiejętności społeczne adekwatne do stanowiska $(37 \%)$ oraz wyższa lojalność wobec pracodawcy (27,4\%), [Szanse i bariery zatrudniania osób w wieku 45+, 2009, s. 163-164].

W koncepcji produktywności w cyklu życia oraz luki produktywności pracownik w starszym wieku postrzegany jest jako nieefektywny. Wyniki badań Kotlikoffa i Wisea [1989], Hellerstein i Neumarka [1995] oraz Hellerstein, Neumarka i Troske [1999] wskazuja, że wiek pracownika ma wpływ na jego produktywność. Kotlikoff i Wise zauważyli, że granica wieku, po przekroczeniu której następuje wyraźne obniżenie produktywności różni się w zależności od grupy pracowników: dla sprzedawców był to 45. rok życia, dla pracowników biurowych 60 . rok życia. W publikacjach Hellerstein i współautorów granicę wieku, powyżej której pracownicy stają się mniej produktywni określono na poziomie 50. roku życia.

Postrzeganie starszych pracowników jako nieefektywnych jest także pochodną interpretacji relacji ich indywidualnej produktywności i uzyskiwanych zarobków. W przekonaniu części pracodawców, nakłady ponoszone z tytułu zatrudniania starszych pracowników przewyższają wartość, jakiej dostarczają oni organizacji [Turek, 2015].

Mimo że wyniki wielu badań [Oster, Hamermesh, 1989; Kotlikoff, Gokhale, 1992; Fair, 1994] wskazują że wynagrodzenia pracowników starszych są wyższe niż młodszych, bardziej produktywnych, w literaturze przedmiotu nie ma jednomyślności co do oceny starszych pracowników jako nieefektywnych. Między innymi w badaniach Dostie'go [2006] wykazano, że luka produktywności powstaje wyłącznie w przypadku niektórych grup pracowniczych. U większości pracowników wysokość wynagrodzenia i produktywność zmieniaja się z wiekiem, ale zmiany te zachodza równolegle i w tym samym kierunku. $\mathrm{Na}$ podstawie przeprowadzonych badań autor stwierdził, że najwyższą produktywnością charakteryzują się pracownicy w wieku 35-55 lat i oni otrzymują najwyższe wynagrodzenia. Wynagrodzenia w tej grupie są wyższe o $13 \%$ niż wynagrodzenia pracowników młodszych, natomiast

3 W badaniu starsi pracownicy zdefiniowani zostali jako osoby będące w wieku 50 lat i więcej. 
produktywność jest wyższa o 15\%. Z kolei pracownicy w wieku 55 lat i więcej zarabiają o $12 \%$ więcej niż młodzi (w wieku poniżej 35 lat) i są od nich o $13 \%$ bardziej produktywni. Jedyną grupa, dla której zaobserwowano występowanie luki produktywności byli pracownicy w wieku 55 lat i więcej z wyższym wykształceniem. Ci pracownicy zarabiali o $39 \%$ więcej niż pracownicy w wieku poniżej 35 lat i byli od nich bardziej produktywni jedynie o 8\%. Autor tłumacząc powstałą w tej grupie lukę produktywności odwołuje się do teorii odroczonej zapłaty i niepisanych kontraktów (implicite contracts) Lazear’a [1979]. Podobnie lukę produktywności dla pracowników w starszym wieku wyjaśnia Turek [2015].

Osoby reprezentujące starsze grupy wiekowe często traktowane sa jako gorsi (niż młodsi) kandydaci do pracy oraz gorsi (niż młodsi) pracownicy [Silverstein, 2008]. Przyczynę negatywnej oceny tej grupy najczęściej stanowi stereotypizacja wiekowa $\mathrm{i}$ związana $\mathrm{z}$ nią dyskryminacja ze względu na wiek. Zjawisko dyskryminacji opartej na kryterium wieku może dotknąć osoby w każdej grupie wiekowej [Drela, 2012]. Wyniki badań wskazuja jednak, że częściej dotyka osób starszych niż młodszych [Richert-Kaźmierska, Stankiewicz, 2014]. W literaturze przedmiotu ten rodzaj dyskryminacji wiekowej nazywa się ageizmem [Butler, 1980; Trempała, Zajacc-Lamparska, 2007; Trempała, 2014].

Zjawisko dyskryminacji wiekowej na rynku pracy wobec osób w wieku 45 lat i więcej nie jest rzadkie [Morgan, Kunkel, 2011, s. 132]. Według American Association for Retired Persons (AARP) ponad 80\% Amerykanów w wieku 45-80 lat szukających pracy doświadcza takiej dyskryminacji [Staying abead of the curve, 2002]. Wyniki badań Rosen i Jerdee [1985] pokazują, że zdecydowana większość pracodawców $(76 \%)$ mając do wyboru kandydatów o tych samych kwalifikacjach, decyduje się na zatrudnienie młodszego. Badania Berger [2006] również potwierdzaja, że pracownicy starsi sa zatrudniani mniej chętnie niż młodsi. Ponadto - młodsi kandydaci do pracy, nawet legitymując się gorszymi kwalifikacjami i osiagając słaby wynik w czasie pierwszej rozmowy kwalifikacyjnej, otrzymuja propozycje powtórzenia rozmowy o pracę i część otrzymuje ofertę zatrudnienia.

Dyskryminacja wiekowa kandydatów do pracy i pracowników może przybierać różne formy, m.in. sposób organizacji i warunki rekrutacji utrudniające lub uniemożliwiające zatrudnienie osoby w określonym wieku na danym stanowisku, ograniczenia wiekowe w dostępie do udziału w szkoleniach, wiekowe (stażowe) ograniczenia możliwości rozwoju kariery zawodowej i awansu zawodowego, organizacja stanowisk pracy $\mathrm{w}$ sposób niesprzyjający pracy osób w określonym wieku [Older workers face discrimination, 2012]. W Polsce pracownicy reprezentujący starsze grupy wiekowe, według Luczak [2005] i Torpe [2004], doświadczają dyskryminacji wiekowej przez działania pracodawców polegające na:

- $\quad$ wywieraniu presji na pracownikach w wieku emerytalnym, aby przeszli na emeryturę i odeszli z firmy,

- $\quad$ takiej organizacji procesu rekrutacji, aby pracownicy w starszym wieku nie spełniali wymogów naboru kandydatów do pracy,

- oferowaniu niskich wynagrodzeń za pracę lub form zatrudnienia niegwarantujących ani bezpieczeństwa socjalnego, ani stabilności finansowej, 
- $\quad$ kierowanie na szkolenia wyłącznie młodszych pracowników,

- niezapewnieniu pracownikom odpowiednich warunków pracy, inicjowanie lub brak działań przeciwdziałających nieprzyjaznej osobom starszym atmosfery pracy.

W teorii ekonomii zjawiska związane z dyskryminacją pracowników ze względu na wiek tłumaczą m.in. koncepcja segmentacji i dyskryminacji statystycznej oraz koncepcja rynku dualnego. Segmentacja statystyczna rynku pracy polega na podziale tego rynku według widocznych, łatwych do określenia cech populacji (w tym wieku). Aby ograniczyć ryzyko przyjęcia niewłaściwego pracownika do pracy, pracodawcy stosują statystyczną segmentację kandydatów. Wykorzystują ich widoczne wyróżniki jako swego rodzaju wskaźniki posiadania przez kandydata poszukiwanych przez pracodawcę cech, umiejętności, kompetencji, sposobów zachowania się itp. Osoby spełniające kryteria kojarzone z niekorzystnym zestawem cech i umiejętności podlegają tzw. dyskryminacji statystycznej. Zostaja w procesie rekrutacji wyeliminowane lub otrzymuja mniej korzystną ofertę pracy. Dzieje się tak mimo tego, że przypisywane poszczególnym kryteriom podziału kandydatów zestawy cech i umiejętności najczęściej oparte są na stereotypowym odbiorze danej grupy [Zwiech, 2013, s. 140]. Jak piszą Kryńska i Kwiatkowski [2013], dyskryminacja statystyczna dotyczy sytuacji, kiedy pracodawcy nieposiadający wszystkich informacji o przydatności danego kandydata, kierują się uogólnieniami i uproszczeniami przypisywanymi całej grupie społecznej, spełniającej dane kryterium.

Fundament koncepcji dualnego rynku pracy stanowi hipoteza o działających równolegle, diametralnie różnych, dwóch kategoriach rynku pracy [Doeringer, Piore, 1971]. Pierwsza kategoria opisywana jest jako pozytywna i pożądana. Pracownicy sa dobrze wykształceni i reprezentują oczekiwane przez pracodawców postawy. Ścieżki kariery zawodowej i rozwoju tych pracowników są jednoznacznie określone. Oferuje się im dobre i trwałe miejsca pracy. Wykonuja prace, za które są wysoko wynagradzani. Bezpieczeństwo pracy tych pracowników gwarantują m.in. umowy zawierane przez pracodawców ze związkami zawodowymi. Dostęp do miejsc pracy na rynku pierwszej kategorii jest mocno ograniczony, ściśle zdefiniowanymi kryteriami rekrutacyjnymi. Rynek pracy drugiej kategorii tworzą miejsca pracy określane jako drugorzędne (wtórny rynek pracy). Cechują się one niskimi wymaganiami kwalifikacyjnymi, niskimi płacami, niskim statusem społecznym i dużą niestabilnością zatrudnienia [Kryńska, Kwiatkowski, 2013]. Drugorzędne rynki pracy zarezerwowane są dla osób defaworyzowanych i dyskryminowanych na rynku pracy, w tym m.in. imigrantów, osób o niskich kwalifikacjach zawodowych, kobiet, osób młodych, bez doświadczenia oraz reprezentujących starsze grupy wiekowe [Jong i in., 2007, s. 492-515].

Osoby $\mathrm{w}$ wieku okołoemerytalnym, które tracą pracę i nie mogą skorzystać z emerytury, literatura przedmiotu klasyfikuje jako „trudnych” bezrobotnych ${ }^{4}$

4 Poza osobami w wieku okołoemerytalnym do grupy ,trudnych” bezrobotnych w literaturze przedmiotu zalicza się także m.in. bezrobotne osoby niepełnosprawne, osoby pozostające bezrobotnymi przez ponad trzy miesiące, kobiety powracające na rynek pracy po urodzeniu dziecka. 
[Dean $\mathrm{i}$ in., 2013; Families and the world of work, 2000, s. 33; Kolosnitsyna, 2007, s. 58]. Wśród przyczyn utrudniających aktywizację zawodową tej grupy wskazuje się m.in.: niski poziom wykształcenia, kwalifikacje i kompetencje nieodpowiadające oczekiwaniom pracodawców, małą elastyczność i niską mobilność zawodowa, stan zdrowia uniemożliwiający wykonywanie niektórych prac, niechęć pracodawców do zatrudniania pracowników w starszym wieku [Dean i in., 2013; Families and the world of work, 2000; Kolosnitsyna, 2007].

Ograniczenia związane z aktywizacją osób bezrobotnych i biernych zawodowo $\mathrm{w}$ wieku okołoemerytalnym tłumaczą także niektóre z założeń teorii poszukiwań na rynku pracy oraz koncepcji krzywej Beveridge'a.

W teorii poszukiwań na rynku pracy punktem wyjścia jest przekonanie o asymetrycznym rozkładzie informacji występujących na rynku pracy. Oznacza to, że osoby poszukujące pracy nie mają, lub mają niepełną wiedzę na temat dostępnych ofert pracy i związanych $z$ nimi stawek płac. W okolicznościach braku przejrzystości na rynku pracy, zainteresowani podjęciem pracy, aby dokonać wyboru właściwej oferty, zostaja zobligowani do poszukiwania informacji ułatwiających im podjęcie ostatecznych decyzji. To wiąże się z koniecznością ponoszenia określonych kosztów i czasu. Jednostka kontynuuje poszukiwanie pracy tak długo, jak oczekiwane efekty (spodziewane płace) są w jej ocenie większe od kosztów tych poszukiwań. W przypadku osób w wieku okołoemerytalnym, szybciej niż u pozostałych grup bezrobotnych może nastąpić zniechęcenie do kontynuowania poszukiwań pracy i wejścia w stan trwałej bierności zawodowej. Wpływają na to m.in.: [Puzio-Wacławik, 2015, s. 142-145; Nagel, 2012, s. 161].

- długi okres trwania bezrobocia determinujący obniżającą się z czasem intensywność poszukiwania pracy, rosnące zniechęcenie i poczucie rozczarowania - ostatecznie prowadzące do przedwczesnego opuszczenia rynku pracy,

- oczekiwanie relatywnie wysokich wynagrodzeń (progowej stawki płac), co wydłuża okres poszukiwań i podnosi koszty znalezienia odpowiedniej oferty, a w rezultacie zmniejsza jej opłacalność,

- „pułapka motywacyjna”, tj. system wsparcia bezrobotnych (w tym świadczenia socjalne, wcześniejsze emerytury, świadczenia przedemerytalne itp.), który może zachęcać osobę uprawnioną do skorzystania z takiego wsparcia do podjęcia decyzji o zaprzestaniu poszukiwań na rynku pracy i trwałym wycofaniu się z niego,

- subiektywna ocena dostępnych ofert pracy $\mathrm{w}$ relacji $\mathrm{z}$ alternatywnymi opcjami, np. opieka nad wnukami lub innymi osobami niesamodzielnymi, zarobkowaniem w tzw. szarej strefie.

Krzywa Beveridge’a wyraża odwrotną zależność pomiędzy wolnymi miejscami pracy a bezrobociem. Wraz ze wzrostem liczby nowych miejsc pracy w gospodarce spada stopa bezrobocia i odwrotnie [Piocha, Dylkiewicz, 2011, s. 10]. Wszelkie przesunięcia wzdłuż krzywej oznaczają zmiany w zakresie popytu na pracę, mające charakter cykliczny [Idczak, 2014]. Z kolei przesunięcie całej krzywej na układzie współrzędnych w lewo lub w prawo oznacza odpowiednio poprawę lub spadek 
efektywności dopasowań na rynku pracy [Bouvet, 2012]. Według Ghayad’a [2013] spadek stopy bezrobocia wśród osób ze starszych grup wiekowych następuje ze znacznym opóźnieniem w stosunku do wzrostu liczby nowych miejsc pracy. Autor dodaje, że w tych grupach zdarzają się także okresy, w których bezrobocie rośnie, pomimo wzrostu liczby nowych miejsc pracy. Równoczesne występowanie wysokiego bezrobocia oraz znacznej liczby nieobsadzonych miejsc pracy oznacza niski poziom efektywności $\mathrm{w}$ zakresie dopasowania podaży siły roboczej i popytu na pracę. W populacji osób bezrobotnych i nieaktywnych zawodowo w wieku okołoemerytalnym trudności w obsadzeniu wolnych etatów mogą stanowić efekt niedopasowania kwalifikacji do potrzeb pracodawców oraz niedostatecznej mobilności zawodowej [dczak, 2014].

Działania ukierunkowane na aktywizację zawodową osób po 50. roku życia wynikaja przede wszystkim z faktu, że duża część tej grupy przedwcześnie przechodzi na emeryturę i tworzy subpopulację „młodych emerytów”. Na koniec II kwartału 2017 roku współczynnik aktywności zawodowej Polaków w wieku 55-64 lata wynosił 50,2\% (dla porównania - w grupie osób w wieku 15-64 lata 69,7\%) ${ }^{5}$ [Aktywność ekonomiczna ludności Polski, 2017]. Średni wiek osób, którym w 2016 roku przyznano emeryturę wynosił 63,3 lat dla mężczyzn i 61 lat dla kobiet. Wśród osób, którym w 2016 roku przyznano emeryturę 2\% stanowily osoby w wieku poniżej 49 lat, zaś 3,6\% - osoby poniżej 55 . roku życia ${ }^{6}$.

Przedwczesne wycofywanie się z rynku pracy osób wchodzących w wiek okołoemerytalny najczęściej tłumaczy się jako skutek oddziaływania czynników wypychających z rynku pracy (push) oraz wciagających w bierność i emeryturę (pull). W badaniu przeprowadzonym przez Główny Urząd Statystyczny [Præejście ₹ pracy na emeryture, 2013, s. 54] wśród powodów wskazywanych jako decydujące o zakończeniu aktywności zawodowej Polaków w wieku 50 lat i więcej były m.in.:

- „spełnienie warunków uprawniających do otrzymania renty/emerytury $(57,6 \%)$

- $\quad$ stan zdrowia lub niezdolność do pracy $(20,0 \%)$,

- brak możliwości kontynuowania pracy zawodowej z powodu osiagnięcia wieku emerytalnego $(7,6 \%)$,

- utrata pracy i/lub brak możliwości znalezienia pracy (5,6\%),

- $\quad$ korzystne warunki finansowe odejścia z pracy $(3,8 \%)$,

- przyczyny rodzinne lub związane z opieką nad innymi $(2,4 \%)$ ".

Zjawisko zainteresowania wczesną emeryturą tłumaczy także socjologiczna teoria starzenia się - teoria wycofania. W teorii wycofania proces starzenia się jednostki wiąże się $\mathrm{z}$ jej stopniowym wycofywaniem $\mathrm{z}$ życia społecznego, tj. rezygnacji z pełnionych ról charakterystycznych dla wieku średniego. Zarówno w ocenie

5 Współczynnik aktywności zawodowej kobiet i mężczyzn w wieku 55-64 lata w II kwartale 2017 roku wynosił odpowiednio: $41,3 \%$ i $60,1 \%$.

6 Dane Zakładu Ubezpieczeń Społecznych, http://psz.zus.pl/kategorie/emerytury/nowoprzyznane [data wejścia 28.11.2017]. 
jednostki i społeczeństwa takie rozwiązanie postrzegane jest jako korzystne. Dla jednostki oznacza ono ograniczenie społecznej presji dotyczącej utrzymania produktywności i możliwość przygotowania się do całkowitego wycofania z życia społecznego, a dla społeczeństwa - stworzenie przestrzeni dla rozwoju bardziej aktywnych i wydajnych osób młodszych [Schroots, 1996, s. 743; Halicki, 2006, s. 255-276]. W teorii wycofania, podobnie jak pozostałych socjologicznych teoriach starzenia się, kluczowe znaczenie dla decyzji podejmowanych przez jednostkę odgrywają: rola i wizerunek osób starszych w społeczeństwie, charakter interakcji zachodzących pomiędzy osobami starszymi a młodszymi, oraz preferowane w społeczeństwie wzorce, wartości i potrzeby społeczne [Kotlarska-Michalska, 2000, s. 147-159].

$\mathrm{Na}$ przeciwległym biegunie „młodych emerytów” literatura przedmiotu opisuje seniorów aktywnych społecznie i zawodowo. W przypadku aktywności zawodowej osoby starsze kontynuuja zatrudnienie także po przekroczeniu formalnego wieku emerytalnego. Postawy i zachowania tej grupy wyjaśniają m.in. koncepcja pomyślnego starzenia się, koncepcja aktywnego starzenia się i socjologiczne teorie starzenia się, w tym teoria aktywności oraz teoria ciagłości.

Podstawę teorii aktywności stanowi przekonanie o chęci i determinacji osób starszych do zachowania aktywności typowej dla wieku średniego tak długo, jak tylko jest to możliwe. W przypadku utraty możliwości wykonywania pewnych działań i odgrywania niektórych ról społecznych ze względu na wiek, poszukują one ich substytutów. Przejście na emeryturę i wycofanie z aktywności zawodowej może zostać zastapione choćby aktywną działalnością w organizacjach społecznych, uczestnictwem w programach uniwersytetów trzeciego wieku, podróżami, zaangażowaniem w opiekę nad innymi członkami rodziny. Przesłanką dla takich zachowań jednostki jest jej dążenie do utrzymania poziomu aktywności, który występował w okresie dojrzałości. W teorii aktywności, to w jaki sposób osoby starsze postrzegają siebie oraz są postrzegane przez społeczeństwo zależy od ról, jakie pełnią i działań, w które są zaangażowane [Schroots, 1996, s. 743; Halicki, 2006, s. 255-276].

Teoria ciagłości zakłada z kolei, że ludzie kontynuuja wzorce pewnych zachowań niezależnie od wieku, w różnych fazach życia. Aktywność w starszym wieku jest zatem naturalna dla osób, które na wcześniejszych etapach swojego życia były aktywne. Nie wyobrażają sobie nagłego, determinowanego wiekiem, wyłączenia zaktywnego udziału w życiu zawodowym czy społecznym. Decyzje dotyczące rezygnacji z pewnych ról i utrzymania innych na starość sa zdeterminowane przez historię danej jednostki i jej dotychczasowy styl życia [Schroots, 1996, s. 743; Halicki, 2006, s. 255-276]. Warunkiem pomyślnego starzenia się według teorii ciagłości jest zachowanie spójności stylu życia w całym okresie jego trwania i utrzymanie ciagłości wewnętrznej (poczucia spójności własnych skłonności oraz dyspozycji obecnych i wcześniejszych, niezależnie od okoliczności i pełnionych ról) i zewnętrznej (stabilnych relacji społecznych). Jak twierdzi Atchley [1989] ludzie nie zmieniają się na starość, a jedynie stają się bardziej sobą. 


\section{Podsumowanie}

Wraz z postępującym starzeniem się ludności i stanowiącym jego konsekwencję pogłębiającym się deficytem w dostępie do zasobów pracy rośnie presja, aby aktywizować zawodowo grupy tradycyjnie mało aktywne. Należą do nich osoby w starszym wieku, które przedwcześnie ${ }^{7}$ decydują się na przejście na emeryturę lub, które pomimo osiagnięcia formalnego wieku emerytalnego, mogłyby i chcą kontynuować zatrudnienie.

Badania dotyczące pracowników w starszym wieku (realizowane w ostatnich latach dość często zarówno w Polsce, jak i innych państwach) pokazują, że z jednej strony są oni doceniani za posiadaną wiedzę, umiejętności i doświadczenie, z drugiej - pracodawcy niechętnie zatrudniają takie osoby, bywa wręcz, że doświadczają one dyskryminacji w miejscu pracy ze względu na swój wiek.

W artykule podjęto próbę uporządkowania pojęcia „pracownik w starszym wieku” oraz przeanalizowania i usystematyzowania odniesień do starszych pracowników zawartych w wybranych teoriach i koncepcjach ekonomicznych. Wyniki analizy wskazuja, że - podobnie jak to ma miejsce w publikowanych obecnie raportach z badań na temat sytuacji starszych pracowników - także w dorobku myśli ekonomicznej nie ma jednomyślności co do ich oceny. Wobec powyższego, w artykule zaproponowano klasyfikację podejść i wyróżniono następujące typy: cenny pracownik, nieefektywny pracownik, gorszy (niż młodszy) kandydat na pracownika oraz pracownik, trudny bezrobotny, młody emeryt oraz aktywny (zawodowo) senior.

\section{Literatura}

Aktywność ekonomiczna ludności Polski II kwartał 2017 roku, 2017, Główny Urząd Statystyczny, Warszawa.

Angus J., Reeve P., 2006, Ageism: A threat to ageing well in 21st century, "The Journal of Applied Gerontology", $\mathrm{nr} 25$.

Atchley P. C., 1989, A continuity theory of normal aging, "The Gerontologist", nr 29.

Baby Boomers Envision Their Retirement: An AARP Segmentation Analysis, 1999, Roper Starch Worldwide Inc., Washington.

Berger E. D., 2006, "Aging" identities: Degradation and negotiation in the search of employment, „Journal of Aging Studies", t. 20.

Borkowski T., Marcinkowski A. 1996 Socjologia bezrobocia, Wydawnictwo Interart, Warszawa.

Bouvet F., 2012, The Beveridge Curve in Europe: New evidence using national and regional data, "Applied Economics", t. 44, nr 27.

Browning G., Worman D., 2008, Gen up. How the four generations work, Chartered Institute of Personnel and Development, London.

7 Przed osiagnięciem ustawowego wieku emerytalnego. 
Budnikowski T., 2002, Berrobocie na swiecie $i$ w Polsce, Prace Instytutu Zachodniego, Poznań.

Butler R. N., 1980, Ageism: A Forward, "Journal of Social Issues", nr 36.

Cavan R. S., 1962, Self and role in adjustment during old age, [w:] Human behawior and social process, A. Rose (red.), Houghton Mifflin, Boston.

Dean A., Clarence E., Noya A., 2013, Tackling long-term unemployment amongst vulnerable groups, OECD LEED.

Dezaktywacja osób w wieku okołoemerytalnym. Raport z badań 2008, Departament Analiz Ekonomicznych i Prognoz Ministerstwo Pracy i Polityki Społecznej, Warszawa.

Domański S.R., 1993, Kapitał lud₹ki i wzrost gospodarczy, PWN, Warszawa.

Doeringer P.B., Piore M., 1971, Internal Labor Markets and Manpower Analysis, Lexington.

Dostie B., 2006, Wages, productivity and aging, dokument elektroniczny, tryb dostępu: [http://www.banqueducanada.ca/wp-content/uploads/2010/09/dostie.pdf, data wejścia 20.01.2015].

Drela K., 2012, Dyskryminacja na polskim rynku pracy - aspekt młodriešy, „Zeszyty Naukowe ZSPB Firma i Rynek", nr 1.

Edukacja i praca: kontelesty - wyzwania - antynomie, R. Gerlach (red.), 2008, Wydawnictwo Uniwersytetu Kazimierza Wielkiego w Bydgoszczy, Bydgoszcz.

Families and the world of work: four country profiles of family-sensitive policies 2000, United Nations, New York.

Fair R., 1994, How fast do old men slow down, "Review of Economics and Statistics", $\mathrm{nr} 76$ (1).

Feyrer J. D., 2004, Demographics and productivity, Dartmouth College, Mimeo.

Fryca J., Maciejewska B., 2010, Analiza postaw i opinii pracodawcón o pracownikach 45+ w województwie pomorskim, [w:] Pracownicy 45+ w przedsiebiorstwie, J. Fryca, B. Maciejewska (red.), PTE, Gdańsk.

Gawrycka M., 2011, Zmiany w poziomie, strukturze i formach zatrudnienia w gospodarce polskiej w latach 1990-2009, Politechnika Gdańska, Gdańsk.

Generational differences, West Midland Family Center, dokument elektroniczny, tryb dostępu: [http://www.wmfc.org/uploads/GenerationalDifferencesChart.pdf, data wejścia 10.03.2016].

Ghhayad R., 2013, A decomposition of shifts of the Beveridge curve, "Public Policy Briefs", Federal Reserve Bank of Boston, nr 13-1.

Greller M. M., Simpson P., 1999, In search of late career: a review of contemporary social science research applicable to the understanding of late career, "Human Resource management review", nr 9(3).

Halicki J., 2006, Spoteczne teorie starzenia sie, [w:] Zostawic ślad na ziemi, M. Halicka, J. Halicki (red.), Wydawnictwo Uniwersytetu w Białymstoku, Białystok.

Havighurst R. J., 1961, Successful aging, "The Gerontologist", nr 1.

Hellerstein J. K., Neumark D., 1995, Production Function and Wage Equation Estima-tion with Heterogeneous Labor: Evidence from a New Matched Employer-Employee Data Set, "National Bureau of Economic Research Working Paper", nr 10325. 
Hellerstein J. K., Neumark D., Troske K.R., 1999, Wages, Productivity, and Worker Characteristics: Evidence from Plant-Level Production Functions and Wage Equa-tions, "Journal of Labor Economics", nr 17(3).

Huber J., Skidmore P., 2003, The new old. Why baby boomers won't be pensioned off?, Demos, London.

Idczak P., 2014, Efektywność mechaniz̨mu dopasowań na rynku pracy w UE, „Edukacja Ekonomistów i Menadżerów", nr 2 (32).

Jacobs E., Worcester R., 1990, We British. Britain Under the MORIscope, Weidenfeld and Nicholson, London.

Jong J., Schalk R., Goessling T., 2007, An Institutional Perspective on the Employment Position of Temporary Workers in the Netherlands, "Industrial Relations", t. 62, nr 3.

Kijak R., Szarota Z., 2013, Starość. Między diagnozq a driataniem, Centrum Rozwoju Zasobów Ludzkich, Warszawa.

Kolostnitsyna M., 2007, The Russian labour market in transition: mechanisms of adjustment and recent trends, [w:] Employment and training policies in Central and Eastern Europe. A transition labour market perspective, J. Koning (red.), Dutch University Press, Amsterdam.

Kotlarska-Michalska A., 2000, Starosí w aspekcie socjologicznym, „Roczniki Socjologii Rodziny" XII, Poznań.

Kotlikoff L., Gokhale J., 1992, Estimating a firm's age-productivity using the present value of workers' earnings, „Quaerterly Journal of Economics”, nr 107(4).

Kotlikoff L., Wise D., 1989, Employee retirement and a firm's pension plan, [w:] The Economics of Aging, D. A. Wise (red.), University of Chicago Press, Chicago.

Kryńska E., 1998, Wybrane teorie rynku pracy a prognozowanie, [w:] E. Kryńska, J. Suchecka, B. Suchecki, Prognoza podaży i popytu na prace $w$ Polsce do roku 2010, Studia i Materiały, Instytut Pracy i Spraw Socjalnych, Warszawa.

Kryńska E., Kwiatkowski E., 2013, Podstawy wiedzy o rynku pracy, Wydawnictwo Uniwersytetu Łódzkiego, Łódź.

Kunasz M., 2004, Teoria kapitatu ludzkiego na tle dorobku myśli ekonomicznej, [w:] Unifikacja gospodarek europejskich: szanse i zagrożenia, A. Manikowski, A. Psyk (red.), Uniwersytet Warszawski, Warszawa.

Kunemund H., Kolland F., 2007, Work and retirement [w:] Ageing in Society: European perspectives on gerontology, J. Bond, P. G. Coleman (red.), Sage, Londyn-Los Angeles.

Kwiatkowska W., 2007, Zmiany strukturalne na rynku pracy w Polsce, Wydawnictwo Uniwersytetu Łódzkiego, Łódź.

Kwiatkowski E., 2002, Bezrobocie: podstawy teoretyczne, Wydawnictwo PWN, Warszawa.

Lazear E. P., 1979, Why is there mandatory retirement? "Journal of Political Economy", nr 87.

Luczak M., 2005, Dyskryminacja ze wagledu na wiek w oczach ludzi starszych. Prezentacja wyników badania przeprowadzonego przez Forum 50+. Seniorzy XXI wieku, [w:] Stop dyskryminacji ze wzgledu na wiek, B. Tokarz (red.), Akademia Rozwoju Filantropii, Warszawa.

Macunovich D. J., 2000, The Baby Boomers, [w:] Macmillan Encyclopedia of Aging, D. Ekerdt (red.), New York. 
Manuelli R., Seshadri A., 2005, Human Capital and the Wealth of Nations, dokument elektroniczny, tryb dostępu: [http://www.nber.org/ confer/2005/efgw05/ manuelli.pdf, data wejścia 10.03.2016].

Mtodosí çy doświadcrenie? Kapitat ludzki w Polsce. Raport podsumownjacy III edycje badań BKL z 2012 roku 2013, J. Górniak (red.), Polska Agencja Rozwoju Przedsiębiorczości, Warszawa.

Morgan L., Kunkel S., 2011, Aging, society, and the life course, Springer Publishing Company, New York.

Munnell A.H., Sass S.A., 2008, Working longer. The solution to the retirement income challenge, Brookings Institution Press, Washington D.C

Nagel K., 2012, Pržeobrażenia polityki pynku pracy na praykeładzie uybranych krajón, „Problemy gospodarcze w ujęciu teoretycznym i praktycznym” Studia Ekonomiczne, Zeszyty Naukowe Uniwersytetu Ekonomicznego w Katowicach, Katowice.

Nowak K., 2011, Status pojecia pracy w teorii krytycznej i teorii ekonomii, Uniwersytet im. Adama Mickiewicza w Poznaniu, Poznań.

Nowicka A., 2008, Starość jako faz̧a sycia cžtowieka, [w:] Wybrane problemy osób starssych, A. Nowicka (red.), Oficyna Wydawnicza Impus, Kraków.

Older workers face discrimination, 2012, European Working Conditions Observatory, dokument elektroniczny, tryb dostępu: [http://www.eurofund.europa.eu/eweco, data wejścia 10.10.2012].

Oster S., Hamermesh D., 1998, Aging and productivity among economists: Note, "Review of Economics and Statistics", nr 80(1).

Piore M. J., 1979, Birds of Passage. Migrant Labor and Industrial Societies, Cambridge University Press, Cambridge.

Pirie M., Worcester R., 1998, The Millennial Generation, Adam Smith Institute, London.

Piocha S., Dylkiewicz R., 2011, Nanki ekonomiczne wobec problemu bezrobocia - teoria i praktyka, [w:] Rynek pracy jako barometr zmian w gospodarce, S. Piocha, G. Przekota (red.), Wojewódzki Urząd Pracy w Szczecinie, Koszalin.

Przejscie zpracy na emeryture, 2013, Główny Urząd Statystyczny, Warszawa.

Przetacznik-Gierowska M., Tyszkowa M., 2004, Psychologia rožwoju człowieka. Zagadnienia ogólne, Wydawnictwo Naukowe PWN, Warszawa.

Puzio-Wacławik B., 2015, Regulacja rynku pracy - krytyczna analiza uybranych teorii, „Zeszyty Naukowe Wyższej Szkoły Ekonomii i Informatyki w Krakowie”, nr 11.

Richert-Kaźmierska A., 2013, Pržedsiębiory pokolenia baby boomers wobec innowacyjności, „Zeszyty Naukowe Uniwersytetu Szczecińskiego. Ekonomiczne Problemy Usług”, nr 795(109).

Richert-Kaźmierska A., 2017, Zmiany w wielkości i strukturæe wieku potencjalnych zasobów pracy w kontekśscie demograficznego starzenia sie populacii - perspektywa regionalna, „Prace Naukowe Uniwersytetu Ekonomicznego we Wrocławiu", nr 465.

Richert-Kaźmierska A., Stankiewicz K., 2014, Dyskryminacja pracownikón w starsaym wieku - mybrane zagadnienia, „Przedsiębiorczość i Zarządzanie”, t. XV, z. 11, cz. II. 
Richert-Kaźmierska A., Wojciechowska K., 2012, Aktywność zawodowa osób w wieku okotoemerytalnym w wojewódz̨twie pomorskim, „Przedsiębiorstwo we Współczesnej Gospodarce", nr 2.

Rosen B., Jerdee T. H., 1985, Older employees: new roles for valued resources, Dow JonesIrwin, Homewood IL.

Rynek pracy i wykluczenie społeczne w kontekśsie percepcii Polaków. Diagnoza spoteczna 2013. Raport tematyczny, I. Kotowska (red.), 2014, Ministerstwo Pracy i Polityki Społecznej, Warszawa.

Schroots J., 1996, Theoretical developments in the psychology of aging, „The Gerontologist”, t. 36, nr 6.

Schultz T. W., 1976, Investment in Human Capital, The Free Press, New York.

Silverstein M., 2008, Meeting the challenges of an aging workforce, "American Journal of Industrial Medicine", nr 51.

Skirbekk V., 2004, Age and Individual Productivity: A Literature Survey, [w:] Vienna yearbook of population research, Feichtinger G. (red.), t. 1, nr 1, Austrian Academy of Sciences Press, Vienna.

Spychalski G. B., 1999, Zarys historii myśli ekonomicznej, PWN, Warszawa.

Stying ahead of the curve: The AARP work and career study, 2002, Washington.

Szanse $i$ bariery zatrudniania osób w wieku 45+w województwie pomorskim 2009. Raport końcony. Wojewódzki Urząd Pracy w Gdańsku, Gdańsk.

Szatur-Jaworska B., 2013, Zatożenia dotyczqce ludzi starych w polskich badaniach spolecznych - rozważania nieteoretyczne, [w:] O spotecznym znaczeniu toঞ̇samości, miejsca i czasu życia. Szkice socjologiczne $i$ gerontologiczne, D. Racew-Sikora, C. Obracht-Prondzyński, M. Kaczmarczyk, P. Czekanowski (red.), Zrzeszenie Kaszubsko-Pomorskie, Gdańsk.

Thorpe E., 2004, Dyskryminacja ze wagledu na wiek w Unii Europejskiej, [w:] My teżseniorsy w UE, Akademia Rozwoju Filantropii, Warszawa.

Tolbize A., 2008, Generational differences in the workplace, Research and Training Center on Community Living University of Minnesota, Minnesota.

Trempała J., 2014, Ageizm a funkcjonowanie i rozwój ludzi starszych, Warmińsko-mazurski Kwartalnik Naukowy Nauki Społeczne, nr 1(9).

Trempała J., Zając-Lamparska L., 2007, Postawy wobec osób starşych: różnice miedżypokoleniowe, „Przegląd Psychologiczny”, t. 50, nr 4.

Tuomi K., Ilmarinen J., Jahkola A., Katajarinne L., Tulkki A., 1998, Work ability Index, Institute of Occupational Health, Helsinki.

Turek K., 2015, Co starzenie sie ludności oznacza dla firm?, Prezentacja multimedialna z Międzynarodowej konferencji: Obraz polskiego rynku pracy w uynikach 5 edycji badań BKL. Wyzwania na dzis i jutro, Warszawa 28.04.2015.

Turek K., Perek-Białas J., 2013, The role of employers opinions about skills and productivity of older workers: Example of Poland, "Employee Relations", t. 35, nr 6.

Unolt J., 1996, Ekonomiczne problemy rynku pracy, Interaet, Warszawa.

Ustawa z dnia 20 kwietnia 2004 r. o promocji zatrudnienia i instytucjach rynku pracy, Dz. U. z 2004 r. nr 99 poz. 1001.

Wilsz J., 2009, Teoria pracy, IMPUS, Kraków. 
Zieliński M., 2008, Wplyw państwa na rynek pracy i decyz̧je zatrudnieniowe przedsiębiorstw, Wydawnictwo Politechniki Śląskiej, Gliwice.

Zwiech P., 2013, Nierówności spoteczno-ekonomiczne w swietle teorii segmentacji rynku pracy, „Ruch Prawniczy, Ekonomiczny i Socjologiczny”, R. LXXV, z. 2. 